\title{
How to Run Your Own Online Business: A Gamification Experience in ESL
}

\author{
Ma Ángeles Hernández-Prados *D, Ma Luisa Belmonte and Juan Carlos Manzanares-Ruiz (D) \\ Deptartment Teoría e Historia de la Educación, Universidad de Murcia, 30100 Murcia, Spain; \\ marialuisa.belmonte@um.es (M.L.B.); juancarlos.manzanaresr@um.es (J.C.M.-R.) \\ * Correspondence: mangeles@um.es
}

Citation: Hernández-Prados, M.Á.; Belmonte, M.L.; Manzanares-Ruiz, J.C. How to Run Your Own Online Business: A Gamification Experience in ESL. Educ. Sci. 2021, 11, 697. https: / / doi.org/10.3390/ educsci11110697

Academic Editors: José Carlos Piñero Charlo, María Teresa

Costado Dios, Enrique

Carmona Medeiro and Fernando Lloret

Received: 20 August 2021

Accepted: 28 October 2021

Published: 31 October 2021

Publisher's Note: MDPI stays neutral with regard to jurisdictional claims in published maps and institutional affiliations.

Copyright: (c) 2021 by the authors. Licensee MDPI, Basel, Switzerland. This article is an open access article distributed under the terms and conditions of the Creative Commons Attribution (CC BY) license (https:/ / creativecommons.org/licenses/by/ $4.0 /)$.

\begin{abstract}
Notwithstanding the importance and relevance of gamification as a topical methodology in education, and after a literature review, there are just a few studies using role-playing games. In order to motivate and facilitate English as second language (ESL) learning of first year of Bachillerato (year 12) students at a public high school in the Region of Murcia (Spain) and following an action research methodology, we design, implement and evaluate a role-playing game, which consists of the creation and management of a company, The Tik Tok School. The results confirm that students felt more comfortable speaking in English because they were more motivated. They also state that during the experience they were more focused on learning rather than winning the game and that they prefer a gamification approach over traditional settings. Furthermore, they have been participating constantly using more English than Spanish. After the data analysis, we conclude that this methodology positively impacts motivation and the acquisition of a second language.
\end{abstract}

Keywords: role-playing games; gamification; second language instruction

\section{Introduction}

Education is important for the development of societies. Therefore, there is a constant search to improve it, in which innovative education plays a crucial role [1], as it involves the implementation of other ways of completing the educational task that contribute to enhancing the behaviors of individuals, organizations and economies. Nowadays, most teachers have opted for innovative education to transform and upgrade educational practice, although there are still many that feel more comfortable with traditional teachercentered methods. Gamification is one of the most significant methodologies within innovative education [2-7], maybe due to the many advantages that it is said to have. It is a groundbreaking methodology that is here to stay, as many others have in the past.

To avoid the usual confusion regarding gamification and some associated terms, some definitions are commonly used. Deterding et al. [8] (p. 1) understood gamification as "the use of game design elements in non-game contexts", in this case, the educational field in order to motivate and engage people [6]. It is a process that contributes to "making activities more game-like" [9] (p. 266), applying the characteristics and benefits of games to realworld processes and problems [7]. Gamification is based on game mechanics, aesthetics and reasoning to motivate and promote learning [10], and the main difference between ludification and gamification is that the former prioritizes the recreational aspect [11], whereas the latter matches the educational curriculum with skills students will need in their lives [12], focusing on competences. For the purposes of this study, gamification is understood as an unbeatable opportunity to generate active learning environments in which students learn curricular content in a relaxed, collaborative, dynamic and experiential environment.

Within the most common elements that make a gamified experience, some stand out: avatars, badges, boards, prizes and stories [5,13]. Visual support can also be used, especially at the beginning of the gamification, to engage the students [14]. Considering the literature review conducted by Dehghanzadeh et al. [15], the most used elements are feedback, 
challenges, points and rewards. The latter is achieved by winning experience points when you master some activity or achieve a milestone [16]. Furthermore, gamified curricular design involves three main elements: abstraction (transform real-world scenarios into a series of challenges), mechanics, and interfaces, which are designed to invite continuous participation [16].

The growing research on gamification has led to the proliferation of gamified educational experiences. Unfortunately, only a few have been evaluated. In fact, there is very little literature on the development and assessment of innovative educational programs [8], so that the debate on the effectiveness and improvements attributed to gamification continue to be open. The relevance of this research is the evaluations that students make of a role-playing gamification experience. The following questions can be answered: To what extent does this innovation promote the motivation and attention of students? Does it really improve learning and academic performance? To what extent does it affect the acquisition and implementation of competencies? Additionally, more specifically in relation to ESL, how does gamification contribute to the improvement of linguistic competence? In this study, students had to create a company from scratch, deciding, in the so-called team meetings, how they are going to run the business, pay their taxes and the best way to advertise themselves. The main objective of the role-playing is learning to become successful Tiktokers, which is why it is named the Tik Tok School. Through this experience, we intend to work on the acquisition of skills focused on economic management, entrepreneurship, communication processes, negotiation and decision making, among others.

There are different types of gamification in the educational field [17]. Regarding the contents, there are two subtypes: the structural one, in which the contents do not vary, but some gamified elements are added, and the content one, in which gamification is applied to both the contents and the structure, to have a game-like appearance, but we can also classify gamification according to whether it is a punctual action or the complete syllabus of a course [2]. From this point of view, the experience carried out is a punctual action in the syllabus of the English course that fits the second of the described modalities.

Precisely, making a new learning environment is one of the multiple challenges that teachers face. Furthermore, once the multiple benefits attributed to gamification are recognized, the question to be asked is: could these benefits be applied in ESL? More specifically, the following research problem was posed: what effects, achievements and difficulties arise from the application of role-playing games in ESL? As we detail throughout this paper, innovative methodologies in education, and more specifically gamification, are increasingly relevant as a method to help secondary school students improve their English skills [3], such as in a role-playing experience using puppets, with results showing that students improved their oral skills such as pronunciation and fluency [18]. Considering this context, this study has a twofold objective. On the one hand, it aims to provide a gamified intervention program, which increases the motivation with which students perceive the ESL class. On the other hand, it analyzes the students' perceptions, within the context of ESL and after carrying out such an intervention, about their proficiency levels, role-playing games, educational gamification and English use during the game.

Specifically, we started from a state of the art of gamification as a methodological resource in the ESL classroom, then moved on to the design, implementation and evaluation of an educational experience based on a role-playing game in which a group of first-year Bachillerato students (Year 12) had to create their own company, facing some difficulties during the process.

\section{Theoretical Framework}

\subsection{Literature Review: Gamificación in English as Second Language}

Since Wittgenstein adapted many board games for teaching English, particularly card games, and coined the concept of language games [19], the literature about this topic has evolved considerably; in fact, there are several gamification experiences related to language learning. More specifically, Dehganzadeh and Dehganzadeh [20] identify English as the 
language in which gamification is most used, mainly to teach vocabulary and, to a lesser extent, grammar.

If we want gamification to be increasingly used when teaching English, we must understand how it is currently being used and design strategies to help teachers implement it. In the study conducted by Singh et al. [21], several ESL experiences are analyzed, and they conclude that new technologies provide teachers with sufficient resources to gamify curricular content. Likewise, students showed more willingness to use mobile applications to learn languages in the future and positively valued the interaction possibilities [22].

Within gamification studies, the use of online quiz-type tools such as Quizzizz or Kahoot! stands out. The main positive aspects highlighted by Jiménez-Sánchez and Gargallo [23] are that they make classes more fun and have a competitive factor. However, role-playing games do not usually use external applications but rely on the creation of a gamified game environment.

In another ESL experience focused on traditional African stories called Ubuntu, students were introduced to different social contexts, approaching other cultures and creating their narratives while expanding their lexical knowledge and understanding better the components of a story. Furthermore, it fostered creativity and critical thinking [24]. Similarly, Lam et al. [25] developed critical thinking and argumentative writing in high-school students through gamification. They conclude that is a more effective method than teacherled direct instruction as it promotes writing longer, more creative and critical texts with the appropriate argumentative and structural components. Moreover, the subsequent on-line discussion allows students to read and reply to their peers' contributions, favoring interaction and feedback.

On the one hand, other investigations analyze the effect of role-playing games on learning English vocabulary, such as the one led by Fahim and Sabah [26]. They had similar results as before: students valued gamification positively and performed better than the control group. Another experience conducted by Girardelli [3] proved that when using gamification and role-playing games, trying to imitate a famous American TV show, students gained confidence when making short interventions in English and were more aware of the importance of organizing their speech and of non-verbal communication. On the other hand, Yen et al. [27] designed a mobile application focused on learning English vocabulary. It showed that students increased the time they spent using English and their proficiency level compared to the control group.

\subsection{The Use of Role-Playing Games in Education}

Of the different gamification approaches, this paper focuses on role-playing games. In 1974, Dungeons and Dragons was published, considered the world's first role-playing game, and it defined many of the characteristics and canons still in use. It established that imagination should be used and emphasized the need to perform a role [28]. A role-playing game could be defined as a shared fiction that develops some type of narrative with no predefined script in which each player assumes a specific role and acts consequently $[29,30]$. This is the main difference with another gamification modality: simulation. For this reason, due to the choices made by the players there will be no two similar role-playing games, even if they are based on the same story. Furthermore, during the game, the characters will develop and obtain new skills [31]. Finally, Mackay [32] adds the idea that a role-playing game must be "episodic", that is, it has to be carried out in several sessions, not just in one.

A role-playing game is a tool that will allow teachers to introduce real life-like activities with which students can understand more deeply a topic. For example, in the study of Gordon [33], students learnt the differences between American and Mexican cultures. Additionally, they acquired new vocabulary such as "pyramid, Aztecs or archaeological dig" (p. 713). Nuriyanti [34] states that to know a language means being able to use it in written and oral form to express your feelings or ideas, regardless of the context. This type of gamified methodologies, such as role-playing games, aim to increase students' level of confidence speaking English so that their oral expression can make quantitative and 
qualitative improvements. Research conducted by Ayuningtias et al. [35], which compares teaching the same content in two ways, traditional memoristic learning and role-playing, showed that students participated more actively in their own learning in the latter. This ended up increasing their enthusiasm, motivation and, therefore, their oral expression skills. As these kinds of games are based on storytelling, they can help pass oral traditions and narratives through mix with popular culture to younger generations.

Like any methodology, gamification has supporters and a detractor who discuss its educational use in an open debate. The former argue that it is an active, student-centered methodology that faces learning with a different attitude and motivation that compensated for the generalized students' disinterest in the curriculum [11]. It is ideal for creating learning environments that actively involve, engage and motivate people and favor conflict resolution in the learning process [10]. It makes ESL classes more fun and, therefore, more motivating for students. The more motivated the students are, the more "effective" the activities carried out [36]. Among role playing games' most motivating characteristics, those that stand out are leaderboards, experience points and badges [4]. Moreover, this methodology promotes students' autonomy and improves leaning outcomes similarly to how the brain learns than traditional teaching [37].

Using role-playing games, students can contribute to blended assessments, seeking new solutions to the posed problems, justifying their opinions and assessing their peers [38]. Likewise, through gamification teachers can assess content in an integrative way [11], so that students feel that their efforts will be rewarded with different instruments not only with a single final evaluation. In another study carried out by Purnama and Nurdianingsih [39], the conclusion is that if we want to improve the oral expression of our students, teachers need to focus on higher order thinking skills and one way to do so is by through roleplaying games

Nevertheless, not everything surrounding gamification and role-playing games is positive. There are also some negative aspects. One of the most mentioned is the difficulty and effort involved in its design, as the teacher must prepare everything thoroughly so that the teaching-learning process achieves the proposed objectives [34]. Jassen [40] supports this idea by arguing that it is a demanding methodology; therefore, the teacher will need to prepare for each experience. In addition to a clear objective that provides content and meaning to the experience, specific training and a certain technological mastery are required to prepare, design and develop each session. These reasons may be the reason that its use is still not very widespread, despite all the potential benefits [12].

As we have presented, there have been several gamification studies in ESL classrooms, with each one using a different technique: mobile applications, video games, role-playing games, etc. Nevertheless, all of them have something in common, the positive assessment and more significant progress of the participants. In the studies presented, motivation, satisfaction, and grades in English increased more in the gamified learning group than in the control group. In fact, in a literature review by Dehghanzadeh et al. [15], the most repeated words about the gamification experience were enjoyable, interactive and exciting, not finding any negative evaluation. Moreover, a role-playing game experience using students studying for an engineering degree showed that the game itself was the most useful learning element during the course [41]. However, other variables such as classroom activities and demographics have not been considered to elaborate on such studies, so the conclusions are still at a preliminary stage [42]. As Ishaq et al. [43] found, mobile learning allows students to learn remotely and adapt their routines to their circumstances. Another app to consider is "Grammar Grabber", which makes it possible to evaluate the student's grammatical knowledge while receiving constant feedback. Moreover, it is possible to repeat incorrect answers [44].

Thanks to role-playing games, students can work on not only the main content but also on some transversal elements-for example, using French as a means of learning about the Enlightenment and the history of France [45]. 


\section{Materials and Methods}

This experimental study is based on an objectivist model, following a quantitative paradigm [46].

\subsection{Participants and Context}

The gamified experience was carried out in a public secondary school of Murcia (Spain), during the academic year 2020-2021.

The participants are part of a bilingual English-Spanish group in their 1st year of Bachillerato (year 12). As can be observed in Table 1, it is made up of 12 students (7 girls and 5 boys). None of them needed educational support. A large majority were 16 years old at the time of the research. It is noteworthy that none of them had lived in an Englishspeaking country and just a few have English-speaking relatives. In addition, most of them do not attend private English classes.

Table 1. Sample distribution of participating students.

\begin{tabular}{cccc}
\hline Variables & Options & Percentage & Frequency \\
\hline \multirow{2}{*}{ Age } & 16 & $75 \%$ & 9 \\
\cline { 2 - 4 } & 17 & $25 \%$ & 3 \\
\hline \multirow{2}{*}{ Gender } & Girl & $58.3 \%$ & 5 \\
\cline { 2 - 4 } & Boy & $41.7 \%$ & 7 \\
\hline \multirow{2}{*}{ Attend private classes } & Yes & $41.7 \%$ & 5 \\
\cline { 2 - 3 } English-speaking relatives & No & $58.3 \%$ & 7 \\
\cline { 2 - 4 } & Yes & $25 \%$ & 3 \\
\hline \multirow{2}{*}{ Lived in an English-speaking country } & No & $75 \%$ & 9 \\
\cline { 2 - 4 } & Yes & $0 \%$ & 12 \\
\hline
\end{tabular}

The most significant aspect is undoubtedly the little contact that the students have with English outside the classroom. As we can see, none of them have lived in an Englishspeaking country and a large majority $(75 \%)$ do not have English-speaking relatives. This is reinforced by the fact that only $41.7 \%$ of the students attend English private classes.

\subsection{Methods}

There are three stages in this investigation. The first one was a literature review about educational gamification. Subsequently, we designed and prepared all the materials used, following the previously studied guidelines. The second phase consisted of the implementation of the role-playing game and the gamified sessions with the students. Once the students had completed the experience, they assessed the experience through a questionnaire. Finally, we analyzed the data collected, considering the following parameters: gender, attendance to English private classes and having English-speaking relatives.

Implementing a gamified didactic unit implies reorganizing the teacher-student relationship, as the game has been designed for peer groups. In this sense, and considering the role-playing game format, formality and professionalism must be two of the main features that mark students' relationships among themselves and with the teacher, since they must remain as true as possible to their assigned characters. Therefore, the terminology and forms of politeness must be appropriate for the situation [47].

The role-playing game is designed to work on the vocabulary, grammar and expressions students have learned during theoretical sessions. It consisted of creating a company, the Tik Tok School, in which the students had to face the challenges of any entrepreneur. Such challenges were to find the first students, how to deal with a tax payment or, once the students arrived, how to run the school successfully. 
Before a role-playing game starts, players must complete a character sheet with basic features and valuable information. This sheet must be updated as the game progresses [48] In our study, we designed three character sheets (Figure 1), depending on the role each student chose. The first one is the CEO, who oversees decisions made at the company as well as makes sure it is profitable; the marketing person, who is in charge of advertising the company on social media; and the teacher, who is responsible for designing the classes. The organizational chart that the students made is in Figure 2. To help them internalize their characters and play their roles as partners in a company, they had to fill in some details such as weaknesses, strengths or objectives. Depending on the moment, the teacher may act as a representative of tax authorities or a television reporter, among others.

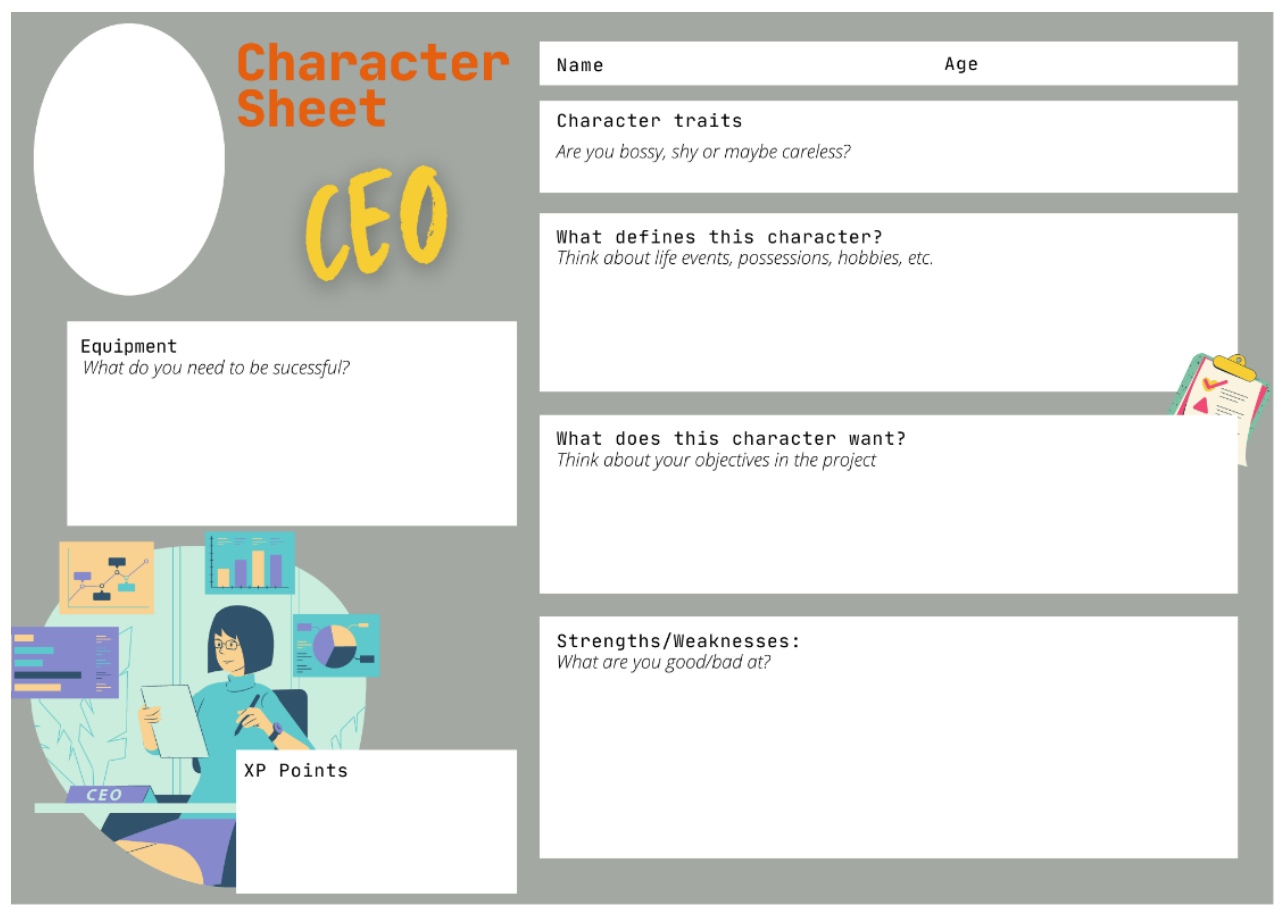

Figure 1. Example of one of the character sheets used in the role-playing game.

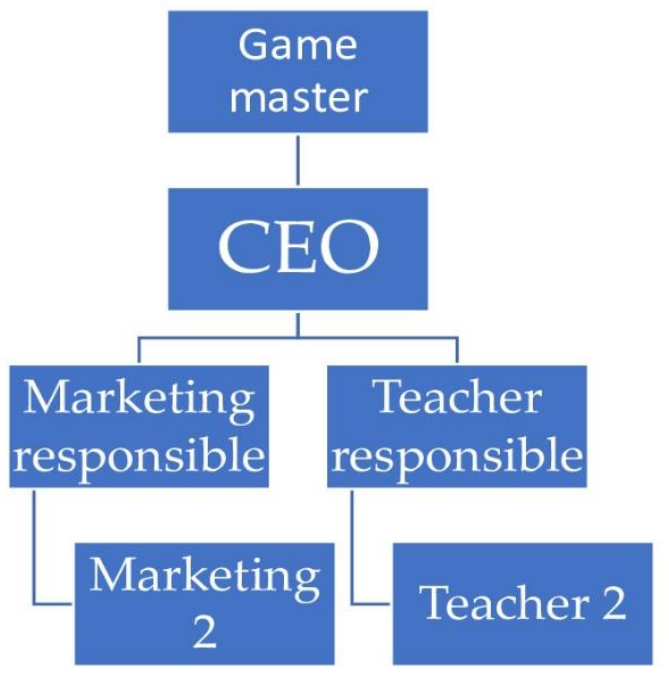

Figure 2. Organizational chart of the company.

On the one hand, a game handbook was designed with the company logo (Figure 3) and the objectives to be achieved in each team meeting, with space to take notes and 
plan the strategies to be followed. We also used task cards that some students received during the experience, such as the letter from Her Majesty's Revenue and Customs (HMRC) (Figure 4), demanding a fine for non-payment.

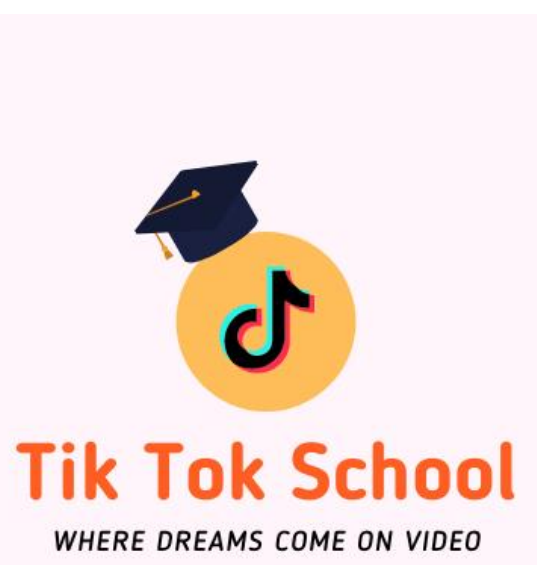

Figure 3. Company logo.

\section{(ID H Revenue \& Customs}

Tik Tok School

King Peter Street, 8

Oxford

\author{
HM Revenue and Customs \\ BX9 1AS \\ London \\ 03001231813 \\ www.hmrc.gov.uk
}

Date of issue: 2nd April 2021

Reference: 120 P M 5632753

New debt - amount due $£ \mathbf{2 0 0 0 . 0 0}$

Dear Sir or Madam,

Our records show that we agreed to a payment plan to help you bring your tax affairs back on track, but that you now have a new debt. You accepted these conditions. That is why you must pay this new debt immediately and ensure that all future tax payments are made on time.

You can pay by debit or credit card by calling us on the number above. To pay online, and for more information about payment, please go to www.hmrc.gov.uk/payinghmrc

Yours faithfully,

Office of Revenue and Customs 
These cards have the function of giving more dynamism to the game, since some characters during the team meetings will have to carry out the secret mission that appears in each one.

On the other hand, gamified activities were integrated within the role-playing game itself. For example, to practice vocabulary related to economy and money, we designed an activity inspired by the board game Taboo. Moreover, we used an activity based on the Battleship game to practice the passive voice. Finally, we used classroom discussions to learn some structures to show agreement/disagreement, ask for someone's opinion, etc.

Likewise, we used two videos (Figure 5) so that students could get into the character more effectively during the game. The first one was used to introduce the experience and to help students choose their characters. We played the second video at the end of the experience. It was a news program showing that the students had won an innovation award. Finally, they had an informative note about the game posted on Google Classroom. It was a summary of how the experience worked.

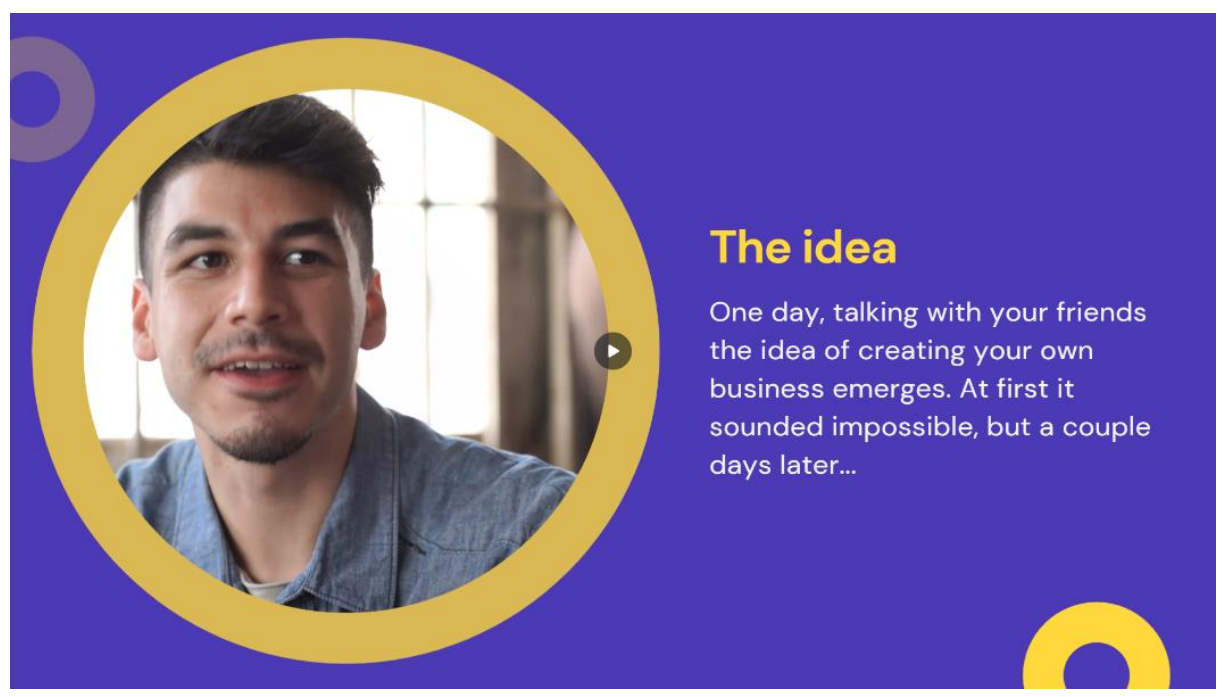

Figure 5. Extract from the introduction video.

Among the ethical considerations that were considered, it should be noted that all participants received relevant information about the project in two different ways: information sheets and an oral presentation in the classroom. As it is an innovative methodology, they were informed that they all had to participate in the learning experience to acquire the didactic unit's curricular competencies. However, they could refuse to participate in the completion of the questionnaire that evaluated it. As the participants were minors, the families received an informed consent form emphasizing that participation in the data collection through the questionnaire was voluntary, and that all data collected were anonymous and kept in a safe place. The choice to participate was not conditioned or pressured, since the research team is external to the educational center, and it was made clear to the students that failure to complete the questionnaire would not affect the grade for the subject, since the subject coordinator would not have this information.

\subsection{Data Collection Instrument}

The questionnaire used [49], which has been previously validated, has the ultimate goal of determining and analyzing the perception that secondary school students have of ESL learning through games and gamification. The instrument is divided into several sections. The first one integrates sociodemographic questions and questions aimed at finding out the students' proficiency levels and relationships with English. The following 28 items are closed-ended, with a five-grade Likert-type scale (1: strongly disagree; 2: disagree; 3: neither agree nor disagree; 4: agree and 5: strongly agree). These are further subdivided 
into four dimensions. The first seven items are dedicated to role-playing games, the next six to the gamification sessions, the following six to the use of the English language in the game and the last nine to find out their general opinion.

\subsection{Data Collection Techniques}

The technique used to analyze the information obtained is statistics and, specifically, descriptive analysis. It is used to summarize the information contained. Version 24.0 of the Statistical Package for the Social Sciences (SPSS) predictive and graphic analytics platform was used for analyzing the data.

\section{Results}

This section may be divided into subheadings. It should provide a concise and precise description of the experimental results, their interpretation, and the experimental conclusions that can be drawn.

\subsection{Students' Perceptions about Their Own Proficiency Level, Once the Gamification Is Over}

The descriptive statistics of the research variables, specifically the mean scores $\left(\mathrm{X}^{\sim}\right)$ and standard deviations $(\sigma)$, of the purpose stated in the study, are shown below.

As Table 2 shows, students' have intermediate proficiency levels $\left(\mathrm{X}_{\mathrm{PA} 1.3}^{\sim}=3.58\right)$. More specifically, they state they have better oral $\left(\mathrm{X}_{\mathrm{PA} 1.4}^{\sim}=3.92\right)$ and written $\left(\mathrm{X}_{\mathrm{PA} 1.5}^{\sim}=3.92\right)$ comprehension. However, their production proficiency levels, both oral $\left(\mathrm{X}_{\mathrm{PA} 1.6}^{\sim}=3.58\right)$ and written $\left(\mathrm{X}_{\mathrm{PA} 1.7}=3.50\right)$, are average.

Table 2. Descriptive statistics of students' perceptions of their English proficiency levels.

\begin{tabular}{lcc} 
& $\mathbf{X}^{\sim}$ & $\sigma$ \\
\hline $\begin{array}{l}\text { A1.3. My overall proficiency } \\
\text { level is: }\end{array}$ & 3.58 & 0.669 \\
\hline $\begin{array}{l}\text { A1.4. My oral comprehension } \\
\text { proficiency level (listening) is: }\end{array}$ & 3.92 & 0.793 \\
\hline $\begin{array}{l}\text { A1.5. My written } \\
\text { comprehension proficiency } \\
\text { level (reading) is: }\end{array}$ & 3.92 & 0.996 \\
\hline $\begin{array}{l}\text { A1.6. My oral production } \\
\text { proficiency level (speaking) is: }\end{array}$ & 3.58 & 0.793 \\
\hline $\begin{array}{l}\text { A1.7. My written production } \\
\text { proficiency level (writing) is: }\end{array}$ & 3.50 & 0.798 \\
\hline
\end{tabular}

4.2. Student's Perceptions about the Use of Role-Playing Games in the ESL Classroom Once the Gamification Is Over

Regarding students' opinions about the use of role-playing games in the English classroom, Table 3 shows that they believe that role-playing games help them improve their speaking $\left(\mathrm{X}_{\mathrm{PB} 1.2}^{\sim}=4.50\right)$ and listening $\left(\mathrm{X}_{\mathrm{PB} 1.1}^{\sim}=4.33\right)$ skills. Moreover, they state that they feel more comfortable and confident to speak English in the classroom $\left(\mathrm{X}_{\mathrm{PB} 1.5}=4.33\right)$ and, above all, board games motivate them to participate more $\left(\mathrm{X}_{\mathrm{PB} 1.6}=4.42\right)$, fostering peer interrelations $\left(\mathrm{X}_{\mathrm{PB} 1.7}^{\sim}=4.08\right)$. 
Table 3. Descriptive statistics of students' perceptions about the use of board games in the ESL classroom.

\begin{tabular}{llc}
\hline & $\mathbf{X}^{\sim}$ & $\sigma$ \\
\hline $\begin{array}{l}\text { B1.1. They help improve my oral } \\
\text { comprehension skills (listening). }\end{array}$ & 4.33 & 0.778 \\
\hline $\begin{array}{l}\text { B1.2. They help improve my oral } \\
\text { production skills (speaking). }\end{array}$ & 4.50 & 0.798 \\
\hline $\begin{array}{l}\text { B1.3. They help improve my written } \\
\text { comprehension skills (reading). }\end{array}$ & 3.75 & 1.215 \\
\hline $\begin{array}{l}\text { B1.4. They help improve my } \\
\text { written production skills (writing). }\end{array}$ & 3.50 & 1.168 \\
\hline $\begin{array}{l}\text { B1.5. They help me to be more } \\
\text { confident when speaking in English }\end{array}$ & 4.33 & 0.778 \\
\hline $\begin{array}{l}\text { B1.6. They motivate me to } \\
\text { participate in class. }\end{array}$ & 4.42 & 0.669 \\
\hline $\begin{array}{l}\text { B1.7. They help meet and get to } \\
\text { know better with my classmates }\end{array}$ & 4.08 & 1.084 \\
\hline
\end{tabular}

\subsection{Students' Perceptions about Educational Gamification in the ESL Classroom Once the} Gamification Is Over

As Table 4 shows, students believed that they all had the opportunity to participate in the game $\left(\mathrm{X}_{\text {PB.2.6 }}=4.75\right)$ and that they have focused more on learning and enjoying rather than on winning $\left(\mathrm{X}_{\text {Рв.2.3 }}^{\sim}=4.75\right)$. Moreover, they participated constantly during the game $\left(\mathrm{X}_{\text {PB.2.2 }}^{\sim}=4.67\right)$ and spoke more in English than in Spanish $\left(\mathrm{X}_{\text {PB.2.1 }}^{\sim}=4.53\right)$.

Table 4. Descriptive statistics of students' perceptions about the educational gamification in ESL.

\begin{tabular}{lcc}
\hline & $\mathbf{X}^{\sim}$ & $\sigma$ \\
\hline $\begin{array}{l}\text { B2.1. I have spoken more in } \\
\text { English than in Spanish }\end{array}$ & 4.53 & 0.559 \\
\hline $\begin{array}{l}\text { B2.2. I have been participating } \\
\text { constantly during the game }\end{array}$ & 4.67 & 0.778 \\
\hline $\begin{array}{l}\text { B2.3. I have been more } \\
\text { focused on learning and } \\
\text { enjoying rather than winning }\end{array}$ & 4.75 & 0.622 \\
\hline $\begin{array}{l}\text { B2.4. I have respected my } \\
\text { classmates' turn to play. }\end{array}$ & 4.42 & 0.793 \\
\hline $\begin{array}{l}\text { B2.5. I have listened to my } \\
\text { classmates and respected their } \\
\text { speaking time }\end{array}$ & 4.25 & 0.866 \\
\hline $\begin{array}{l}\text { B2.6. Everyone could } \\
\text { participate more than once } \\
\text { during the game }\end{array}$ & 4.75 & 0.622 \\
\hline
\end{tabular}

\subsection{Students' Perceptions about the Use of English during the Game Once the Gamification} Is Over

As reflected in Table 5, students claim to have been able to understand their peers' points of view $\left(\mathrm{X}_{\text {PB.3.2 }}^{\sim}=4.42\right)$, having always or almost always used English to communicate $\left(X_{\text {PB.3.3 }}^{\sim}=4.42\right)$. In addition, they stated they have always or almost always answered in English to the teacher $\left(\mathrm{X}_{\text {PB.3.6 }}^{\sim}=4.25\right)$, understanding all or almost all conversations held in English with peers and/or the teacher $\left(\mathrm{X}_{\mathrm{PB} .3 .1}^{\sim}=4.25\right)$. 
Table 5. Descriptive statistics of students' perceptions about the use of English during the gamification.

\begin{tabular}{lcc}
\hline & $\boldsymbol{X}^{\sim}$ & $\sigma$ \\
\hline $\begin{array}{l}\text { B3.1. I have understood all or almost all } \\
\text { conversations held in English with my } \\
\text { classmates and/or the teacher. }\end{array}$ & 4.25 & 0.588 \\
\hline $\begin{array}{l}\text { B3.2. I have been able to understand my } \\
\text { classmates' points of view. }\end{array}$ & 4.42 & 0.793 \\
\hline $\begin{array}{l}\text { B3.3. I have spoken in English always or } \\
\text { almost always to speak with my classmates. }\end{array}$ & 4.42 & 0.900 \\
\hline $\begin{array}{l}\text { B3.4. I have spoken in English always or } \\
\text { almost always with the teacher. }\end{array}$ & 4.08 & 0.669 \\
\hline $\begin{array}{l}\text { B3.5. I have been able to answer always or } \\
\text { almost always in English to my classmates } \\
\text { when they have posed a question. }\end{array}$ & 4.08 & 0.793 \\
\hline $\begin{array}{l}\text { B3.6. I have been able to answer always or } \\
\text { almost always in English with the teacher } \\
\text { when he has posed a question. }\end{array}$ & 4.25 & 0.754 \\
\hline
\end{tabular}

\subsection{Students' General Perceptions about the Gamified Experience}

Finally, as Table 6 shows, students assess gamification sessions as a very effective tool to improve their English proficiency level $\left(\mathrm{X}_{\mathrm{PB} .4 .2}^{\sim}=4.75\right)$. Moreover, they generally prefer them to other types of activities $\left(X_{\text {PB.4.3 }}^{\sim}=4.58\right)$, because they are, according to them, more entertaining than a traditional session $\left(\mathrm{X}_{\mathrm{PB} .4 .1}^{\sim}=4.58\right)$. In addition, they find it a very good idea to learn English while playing $\left(X_{\text {PB.4.4 }}^{\sim}=4.67\right)$.

Table 6. Descriptive statistical of students' perceptions about their general opinion about the experience.

\begin{tabular}{llc}
\hline & $\boldsymbol{X}^{\sim}$ & $\boldsymbol{\sigma}$ \\
\hline $\begin{array}{l}\text { B4.1. I like the gamification sessions because } \\
\text { they are entertaining and motivate me to } \\
\text { continue learning. }\end{array}$ & 4.58 & 0.669 \\
\hline $\begin{array}{l}\text { B4.2. I believe that the gamification sessions } \\
\text { are effective to improve my English } \\
\text { proficiency level. }\end{array}$ & 4.75 & 0.622 \\
\hline $\begin{array}{l}\text { B4.3. I prefer these activities than the usual } \\
\text { ones that I do in ESL classes. }\end{array}$ & 4.58 & 0.669 \\
\hline $\begin{array}{l}\text { B4.4. I think it is a good idea to learn English } \\
\text { while I play. }\end{array}$ & 4.67 & 0.651 \\
\hline $\begin{array}{l}\text { B4.5. Instructions have been clear and easy } \\
\text { to understand. }\end{array}$ & 4.42 & 0.793 \\
\hline B4.6. There has been enough playing time. & 4.42 & 0.900 \\
\hline B4.7. The classes were well organized. & 4.67 & 0.651 \\
\hline $\begin{array}{l}\text { B4.8. The game materials are related to the } \\
\text { topics learned in the didactic unit. }\end{array}$ & 4.58 & 0.793 \\
\hline B4.9. I found it easy to follow the activities. & 4.42 & 0.79 \\
\hline
\end{tabular}

\section{Discussion}

Throughout the study, we have been detailing the benefits that role-playing games and educational gamification in general regarding motivation and improving students' outcomes $[6,23,36,39]$. Therefore, the relevance and appropriateness of the design, implementation and evaluation of gamified didactic units in the classroom are amply justified. Furthermore, the results obtained show that students prefer gamified sessions to tradi- 
tional teaching methods. This verifies what has been previously stated by authors such as Sarmiento et al. [11], Kapp [10], Hernández-Ramos and Belmonte [36] or Rueckert et al. [37].

The role-playing game described in this paper was based on creating a company, improving the disciplinary curricular content and the students' entrepreneurship skills, teamwork and motivation. Although there is no perfect methodology to work on entrepreneurship, the results can be improved as it is an experiential learning tool [50]. Moreover, gamification can achieve the paradigm shift from teacher-centeredness to student-centered teaching [11].

Regarding their English proficiency levels, students started from an average perception in all skills: listening, reading, speaking and writing, with the last two being the lowest ones, and therefore the ones that need to be improved. Even though speaking is always the most difficult skill that students find, they do not practice enough due to practical difficulties, such as anxiety, embarrassment or mistake phobia [51]. The results obtained after the evaluation of the experience by the students indicate that the skill they claim they most improved is speaking. As we have previously indicated, gamification had very positive results for teaching verb tenses [5], vocabulary [52] and for fostering more interaction among students [22]. In fact, some studies claim that through role-playing games students improve this skill as they express themselves actively and meaningfully, while fostering their creativity [53].

On the other hand, the scientific discourse on gamification in terms of the gender variable has a long history in which the initial supremacy of men in the video game industry led not only to the proliferation of men playing them, but also to an exaltation of sexualized women. However, the review by Lynch et al. [54] notes a greater presence of women as protagonists in games and a clear preference for role-playing games over other types of games and less sexualized features. In terms of teamwork, it should be noted that during the gamified intervention using role-playing games, students consider that everyone has had the opportunity to participate in the game, having focused more on learning and enjoying themselves than on winning. Role-playing games are a tool with which students must work in teams to achieve the same objectives, as they would do in the real world [55]. In addition, they claim to have maintained a constant level of participation throughout the game, having spoken more in English than in Spanish.

It is also worth mentioning the positive evaluations they make about how motivating the experience is, being a direct consequence of this, they feel more comfortable speaking English in the classroom, corroborating the studies of Sarmiento et al. [11] and Kapp [10].

Finally, we would like to mention the future possibilities and limitations of this study. Undoubtedly, the most important one is the limited number of participants with whom we could work. It would be advisable to repeat the experience with more students and a control group. Moreover, if it could be repeated in another educative context, i.e., with a non-bilingual class, more complete conclusions could be drawn.

In other previous studies in which gamification and role-playing games have been used to teach curricular content, other sociodemographic variables have not been considered [42]. Therefore, although all the results corroborate the relevance of this methodology, it is necessary to know the context in which we are working to maximize the results.

One of the difficulties related to the teaching-learning process, and not so much to the game itself, stems from having to work collaboratively in hybrid educational contexts derived from the COVID situation [56], and with the need to maintain social distance. Due to the use of masks, it was really complicated to understand the pronunciation, the gesticulation and dramatization accompanying the role-playing games, the preparation and work of the group outside the school premises, the exchange of materials, etc.

On the other hand, some difficulties derived from the designed game were detected regarding the excessively specialized and technical vocabulary used in some elements of it, such as the HMRC letter. The lack of experience of the students in these dynamics was reflected in the insecurity of not controlling the game and how the decisions taken in each of the challenges affected them, as well as in the lack of criteria, knowledge and 
arguments for making business decisions, making it difficult to stimulate the debates in the work groups. Moreover, the lack of familiarity with the role-playing strategy, shyness and fear of communicating in the classroom, together with the work overload for teachers and students, are two of the limitations associated with the game itself [57].

Regarding the teacher-student relationship, the role as facilitator played by the former should be emphasized. Sometimes students get carried away by fun and entertainment, overshadowing learning; therefore, it is important that the teacher acts as a moderator, taking control of all roles, redirecting the process and fostering students' motivation and their intention to act $[58,59]$. They were to act as different characters depending on the situation, whether as a television reporter or someone looking for information about the school. Moreover, it has been demonstrated that the teacher also enjoyed these kinds of games and is looking forward to seeing how the game develops [18]. There were some moments when the students were stuck, so he would intervene by mentioning some guidelines for them to follow. Furthermore, in the team meetings, the teacher would ask questions to stimulate the discussions and to encourage new ideas. He needs to be supportive through feedback, to help students overcome the fear of speaking in public and to create a climate of trust and respect. Thanks to this, students become more spontaneous and enthusiastic [57].

As this was a gamification experience in ESL, the teacher also had to resolve the linguistic doubts that arose, both so that the students could express themselves and so that they could understand the situations that were being presented. Finally, the role of the teacher was basically that of a game master, i.e., the person in charge of the game, of setting the timing, of establishing and finalizing new challenges, among others.

Some of the challenges that the students faced as entrepreneurs were, first, to find an innovative idea. Role-playing games can raise awareness of entrepreneurial spirit [60], which is a powerful economic tool for the future of a country [61]. However, as this was partially delimited in the introduction of the role-playing game, the students had to show their creativity in delimiting the aspects of content, marketing, target audience, structure, organization chart of the company, etc. Afterwards, they had to look for a way to finance their project and, once this was obtained, to pay their taxes. When the company was operational, one of the main difficulties encountered by any entrepreneur or worker is managing business conflicts and interpersonal relations between workers and employers. Persuasive communication, which is vital in the business world and not so often taught in schools [60], is a key element of these relationships and one way to work on this is through role-playing games as they foster students' confidence when speaking. Regarding conflicts, role-playing games positively influence students' self-efficacy in problem solving, critical thinking and teamwork [62]. This is supported by another study which concludes that entrepreneurship education through role-playing games is a completely effective and valid method [61]. As Radianto and Santoso [63] state, the entrepreneurship process has two main aspects: the financial and non-financial ones. It is crucial that the teacher understands how students are running their business to give them proper guidance.

In conclusion, we would like to highlight the importance that gamification and other innovative methodologies have and will have in education due to their educational implications and the good results they have been obtaining. Similarly, we would like to emphasize the need for teachers to be trained in gamification, which, as indicated by Jassen [40], is a very demanding methodology for them. However, as have been detailed in gamification studies, they achieve excellent results $[15,35,52]$. In addition, we believe that more training in new technologies and innovative methodologies will reduce the time needed to create new gamified experiences and the insecurity of some teachers when employing them in the classroom [64].

Author Contributions: Conceptualization, M.Á.H.-P. and J.C.M.-R.; methodology, M.L.B.; validation, M.Á.H.-P. and M.L.B.; formal analysis, J.C.M.-R.; investigation, J.C.M.-R.; resources, J.C.M.-R.; data curation, M.L.B.; writing—original draft preparation, J.C.M.-R.; writing—review and editing, M.Á.H.-P. 
and M.L.B.; visualization, M.Á.H.-P.; supervision, M.Á.H.-P. and M.L.B.; project administration, M.Á.H.-P. All authors have read and agreed to the published version of the manuscript.

Funding: This research received no external funding.

Institutional Review Board Statement: The study was conducted according to the guidelines of the Declaration of Helsinki. and the protocol was approved by the schools where the study took place.

Informed Consent Statement: Informed consent was obtained from all subjects involved in the study. Moreover, the school involved authorized this research project.

Data Availability Statement: The data presented in this study are available on request from the corresponding author. The data are not publicly available due to privacy.

Acknowledgments: We would like to thank the teachers, students and families of the high school where the project was developed for the possibility of developing it.

Conflicts of Interest: The authors declare no conflict of interest.

\section{References}

1. Aithal, P.S.; Aithal, S. An innovative education model to realize ideal education system. Int. J. Sci. Res. Manag. (IJSRM) 2015, 3, 2464-2469.

2. Garone, P.; Nesteriuk, S. Gamification and Learning: A Comparative Study of Design Frameworks. In Digital Human Modeling and Applications in Health, Safety, Ergonomics and Risk Management; Duffy, V., Ed.; Healthcare Applications, HCII 2019; Lecture Notes in Computer Science; Springer: Cham, Switzerland, 2019; Volume 11582, pp. 473-487.

3. Girardelli, D. Impromptu speech gamification for ESL/EFL students. Commun. Teach. 2017, 31, 156-161. [CrossRef]

4. Hamari, J.; Koivisto, J.; Sarsa, H. Does Gamification Work?-A Literature Review of Empirical Studies on Gamification. In Proceedings of the Hawaii International Conference on System Sciences, Waikoloa, HI, USA, 6-9 January 2014; pp. 3025-3034. [CrossRef]

5. Sourav, A.I.; Lynn, N.D.; Suyoto, S. Teaching English tenses in an informal cooperative study group using smart multimedia and gamification. IOP Conf. Ser. Mater. Sci. Eng. 2021, 1098, 032035. [CrossRef]

6. Su, C.-H.; Cheng, C.-H. A mobile gamification learning system for improving the learning motivation and achievements. J. Comput. Assist. Learn. 2014, 31, 268-286. [CrossRef]

7. Wortley, D. The Future of Serious Games and Immersive Technologies and Their Impact on Society. In Trends and Applications of Serious Gaming and Social Media; Springer: Singapore, 2014; pp. 1-14. [CrossRef]

8. Deterding, S.; Dixon, D.; Khaled, R.; Nacke, L. From game design elements to gamefulness: Defining gamification. In Proceedings of the 15th International Academic MindTrek Conference: Envisioning Future Media Environments, Tampere, Finland, 28-30 September 2011; ACM: New York, NY, USA, 2011.

9. Werbach, K. (Re)Defining Gamification: A Process Approach, persuasive technology. Lect. Notes Comput. Sci. 2014, 266-272. [CrossRef]

10. Kapp, K. The Gamification of Learning and Instruction: Game-Based Methods and Strategies for Training and Education; John Wiley \& Sons: Hoboken, NJ, USA, 2012.

11. Sarmiento, B.R.; Prados, M.H.; Bernal, N.C.; Gómez, M.C.A. Alfabetización del profesorado en gamificación mediada por las TIC. Estado del arte. Med. Educ. 2021, 12, 53-65. [CrossRef]

12. Peris, F.J.S.I. Gamificación. Educ. Knowl. Soc. (EKS) 2015, 16, 13-15. [CrossRef]

13. Parreño, J.M.; Ibáñez, E.M.; Arroyo, A.A. The use of gamification in education: A bibliometric and text mining analysis. J. Comput. Assist. Learn. 2016, 32, 663-676. [CrossRef]

14. Villagrasa, S.; Fonseca, D.; Redondo, E.; Duran, J. Teaching Case of Gamification and Visual Technologies for Education. J. Cases Inf. Technol. 2014, 16, 38-57. [CrossRef]

15. Dehghanzadeh, H.; Fardanesh, H.; Hatami, J.; Talaee, E.; Noroozi, O. Using gamification to support learning English as a second language: A systematic review. Comput. Assist. Lang. Learn. 2019, 1-24. [CrossRef]

16. Yunyongying, P. Gamification: Implications for Curricular Design. J. Grad. Med. Educ. 2014, 6, 410-412. [CrossRef] [PubMed]

17. Kapp, K.; Blair, L.; Mesch, R. The gamification of learning and instruction fieldbook. In Ideas into Practice; Wiley: Hoboken, NJ, USA, 2013.

18. Kurniatun, F.; Suhartono, L.; Wardah, W. Improving students' speaking skill through role play activity by using hand puppet. J. Pendidik. Dan Pembelajaran Khatulistiwa 2020, 9, 1-9.

19. Das, D.; Neog, R. Language game: Ludwig wittgenstein. Int. J. Manag. 2020, 11, 143-148. [CrossRef]

20. Dehganzadeh, H.; Dehganzadeh, H. Investigating effects of digital gamification-based language learning: A systematic review. J. Engl. Lang. Teach. Learn. 2020, 12, 53-93.

21. Singh, C.; Ong, E.; Singh, T. A review of research on teachers' views on integrating gamification and technology in english as second language classroom. J. Crit. Rev. 2020, 7, 4333-4341. [CrossRef] 
22. Abarghoui, M.A.; Taki, S. Measuring the Effectiveness of Using "Memrise" on High School Students' Perceptions of Learning EFL. Theory Pract. Lang. Stud. 2018, 8, 1758-1765. [CrossRef]

23. Jiménez-Sánchez, M.; Gargallo, N. Gamification and Students' Motivation: Using Quizizz in the English as a Foreign Language (efl) Classroom. Studia Universitatis Petru Maior. Philologia 2020, 2, 143-157. Available online: https://www.proquest.com/ scholarly-journals / gamification-students-motivation-using-quizizz/docview/2475532461/se-2?accountid=17225 (accessed on 23 March 2021).

24. Oliveira, S.; Porto, I.P.D.; Cruz, M. The Gamification Octalysis Framework within the Primary English Teaching Process: The Quest for a Transformative Classroom. Rev. Lusófona Educ. 2018, 41, 63-82. [CrossRef]

25. Lam, Y.W.; Hew, K.F.; Chiu, K.F. Improving argumentative writing: Effects of a blended learning approach and gamification. Lang. Learn. Technol. 2017, 22, 97-118.

26. Fahim, M.; Sabah, S. An Ecological Analysis of the Role of Role-play Games as Affordances in Iranian EFL Pre-university Students' Vocabulary Learning. Theory Pract. Lang. Stud. 2012, 2, 1276. [CrossRef]

27. Yen, L.; Chen, C.; Juang, H. Effects of Mobile Game-Based English Vocabulary Learning APP on Learners' Perceptions and Learning Performance: A Case Study of Taiwanese EFL Learners. Academic Conferences International Limited: Sonning Common, UK, 2016.

28. Mentzer, F. Dungeons \& Dragons: Players Manual; TSR Hobbies Inc.: Lake Geneva, WI, USA, 1983.

29. Moreno-Guerrero, A.-J.; Rodríguez-Jiménez, C.; Gómez-García, G.; Navas-Parejo, M.R. Educational Innovation in Higher Education: Use of Role Playing and Educational Video in Future Teachers' Training. Sustainability 2020, 12, 2558. [CrossRef]

30. Nellhaus, T. Online Role-playing Games and the Definition of Theatre. New Theatr. Q. 2017, 33, 345-359. [CrossRef]

31. Ntokos, K. Swords and sorcery: A structural gamification framework for higher education using role-playing game elements: Association for Learning Technology Journal. Res. Learn. Technol. 2019, 27. [CrossRef]

32. Mackay, D. The Fantasy Role-Playing Game: A New Performing Art; McFarland \& Company: Jefferson, MO, USA, 2001.

33. Gordon, T. Using Role-Play to Foster Transformational and Social Action Multiculturalism in the ESL Classroom. TESOL J. 2012, 3, 698-721. [CrossRef]

34. Nuriyanti, K. Using Role-Play Techniques to Improve Speaking Ability for Students in the Classroom; Universidad Islámica de Malang: Medina, Saudi Arabia, 2017.

35. Wulandari, W.; Ayuningtias, D.O.; Yana, Y. The use of role play to improve students' speaking skill. Proj. Prof. J. Engl. Educ. 2019, 2, 416-420. [CrossRef]

36. Hernández-Ramos, J.P.; Belmonte, M.L. Evaluación del empleo de Kahoot! en la enseñanza superior presencial y no presencial. Educ. Knowl. Soc. (EKS) 2020, 21, 13. [CrossRef]

37. Rueckert, D.; Pico, K.; Kim, D.; Sánchez, X.C. Gamifying the foreign language classroom for brain-friendly learning. Foreign Lang. Ann. 2020, 53, 686-703. [CrossRef]

38. Dorion, K.R. Science through Drama: A multiple case exploration of the characteristics of drama activities used in secondary science lessons. Int. J. Sci. Educ. 2009, 31, 2247-2270. [CrossRef]

39. Purnama, Y.I.; Nurdianingsih, F. The Impact of Higher Order Thinking Skills (HOTS) Instructions in Teaching EFL Speaking Skill from the Perspective of Students' Motivation. Lingua Cult. 2019, 13, 313-319. [CrossRef]

40. Jassem, K. Teaching gamification. In Proceedings of the 7th International Conference on Education and New Learning Technologies (EDULEARN), Barcelona, Spain, 6-8 July 2015.

41. McConville, J.R.; Rauch, S.; Helgegren, I.; Kain, J.-H. Using role-playing games to broaden engineering education. Int. J. Sustain. High. Educ. 2017, 18, 594-607. [CrossRef]

42. Shortt, M.; Tilak, S.; Kuznetcova, I.; Martens, B.; Akinkuolie, B. Gamification in mobile-assisted language learning: A systematic review of Duolingo literature from public release of 2012 to early 2020. Comput. Assist. Lang. Learn. 2021, 1-38. [CrossRef]

43. Ishaq, K.; Zin, N.A.M.; Rosdi, F.; Jehanghir, M.; Ishaq, S.; Abid, A. Mobile-assisted and gamification-based language learning: A systematic literature review. PeerJ Comput. Sci. 2021, 7, e496. [CrossRef] [PubMed]

44. Ramadoss, R.; Wang, Q. Evaluation of a web-based assessment tool for learning grammar at the primary school level. Int. J. Contin. Eng. Educ. Life-Long Learn. 2012, 22, 175. [CrossRef]

45. Eick, D.; Guikema, J.P. Games as 'Defining Moments' of the College Experience: The Impact of Reacting to the Past in French. Fr. Rev. 2019, 93, 159-174. [CrossRef]

46. García-Sanz, M. Fundamentos Teóricos y Metodológicos de la Evaluación de Programas; Marín, D., Ed.; Routledge: Oxfordshire, UK, 2012.

47. Salán, N.; Rupérez, E.; Illescas, S.; Jorba, J.; Llumà, J.; Rodríguez, D.; Torres, Y. El Juego de Rol Como Metodología Activa. En M. Mata Montes, Innovación Educativa en Las Enseñanzas Técnicas; Universidad de Castilla-La Mancha: Ciudad Real, Spain, 2015; pp. 1509-1518.

48. Almenar, V.; Maldonado, M.; Hernández-Sancho, F. Una aproximación Didáctica a la Contratación Bursátil a Través de un Juego de rol en Google-Docs. Rev. De Docencia Univ. 2009, 7. Available online: https://revistas.um.es/redu/article/view/92601 (accessed on 3 April 2021). [CrossRef]

49. Hernández-Prados, M.A.; Belmonte, M.L.; García-Cantero, I. Validación de un instrumento de recogida de información sobre juegos de mesa en la enseñanza de inglés como lengua extranjera. Estudios 2021, 2, 1-23. [CrossRef] 
50. Huq, A.; Gilbert, D. All the world's a stage: Transforming entrepreneurship education through design thinking. Educ. + Train. 2017, 59, 155-170. [CrossRef]

51. Thao, T.Q.; Nguyet, D.T.N. Four aspects of English speaking difficulties encountered by tertiary English-majored students. Soc. Sci. 2020, 9, 53-64. [CrossRef]

52. Chiang, H.-H. Kahoot! In an EFL Reading Class. J. Lang. Teach. Res. 2020, 11, 33-44. [CrossRef]

53. Rojas, M.A.; Villafuerte, J. The Influence of Implementing Role-play as an Educational Technique on EFL Speaking Development. Theory Pract. Lang. Stud. 2018, 8, 726-732. [CrossRef]

54. Lynch, T.; Tompkins, J.E.; Van Driel, I.I.; Fritz, N. Sexy, Strong, and Secondary: A Content Analysis of Female Characters in Video Games across 31 Years. J. Commun. 2016, 66, 564-584. [CrossRef]

55. Sancho-Thomas, P.; Fuentes-Fernández, R.; Fernández-Manjón, B. Learning teamwork skills in university programming courses. Comput. Educ. 2009, 53, 517-531. [CrossRef]

56. Nieto-Escamez, F.A.; Roldán-Tapia, M.D. Gamification as Online Teaching Strategy During COVID-19: A Mini-Review. Front. Psychol. 2021, 12, 648552. [CrossRef] [PubMed]

57. Sepúlveda, H. Promoviendo aprendizajes significativos en la enseñanza universitaria de la Historia a través de un juego de roles. Estud. Pedagóg. 2020, 46, 97-121. [CrossRef]

58. Reeve, J. Teachers as Facilitators: What Autonomy-Supportive Teachers Do and Why Their Students Benefit. Elementary Sch. J. 2006, 106, 225-236. [CrossRef]

59. Luna, Y.; Conde, A.; Rincón, P. Propuesta Didáctica para el Mejoramiento de la Lectura y Escritura: El Juego de Rol en la Virtualidad. Rev. Conoc. Investig. Y Educación. CIE 2021, 1, 31-43. Available online: http:/ / revistas.unipamplona.edu.co/ojs_ viceinves/index.php/CIE/article/view/4462 (accessed on 5 April 2021).

60. Kirk, G.A. Using role play exercises to enhance communication competence and persuasive communication skills in entrepreneurship programs. Issues Inf. Syst. 2018, 19, 217-225.

61. Hasmawaty, H.; Syam, H.; Saman, A. Validity, Practicality, and Effectiveness: The Last Step in Development of Entrepreneurship Education Based Role-Playing for Kindergarten. Univers. J. Educ. Res. 2020, 8, 8092-8101. [CrossRef]

62. Humpherys, S.L.; Bakir, N.; Babb, J. Experiential learning to foster tacit knowledge through a role play, business simulation. J. Educ. Bus. 2021, 96, 1-7. [CrossRef]

63. Radianto, W.E.D.; Santoso, E.B. Start-Up Business: Process and Challenges in Entrepreneurship Education. Mediterr. J. Soc. Sci. 2017, 8, 97-110. [CrossRef]

64. An, Y.; Zhu, M.; Bonk, C.J.; Lin, L. Exploring instructors' perspectives, practices, and perceived support needs and barriers related to the gamification of MOOCs. J. Comput. High. Educ. 2020, 33, 64-84. [CrossRef] 